\title{
Specific Action of the Lipoxygenase Pathway in Mediating Angiotensin II- induced Aldosterone Synthesis in Isolated Adrenal Glomerulosa Cells
}

\author{
Jerry L. Nadler, Rama Natarajan, and Naftali Stern \\ Sections of Endocrinology, University of Southern California/Los Angeles County Medical Center, Los Angeles, California 90033; \\ Sepulveda Veterans Administration Medical Center, UCLA-San Fernando Valley Program, Sepulveda, California 91343
}

\begin{abstract}
Angiotensin II (AII) in adrenal glomerulosa cells activates phospholipase $\mathrm{C}$ resulting in the formation of inositol phosphates and diacylglycerol rich in arachidonic acid (AA). Although glomerulosa cells can metabolize AA via cyclooxygenase (CO), this pathway plays little role in aldosterone synthesis. Recent evidence suggests that the lipoxygenase (LO) pathway may be important for hormonal secretion in endocrine tissues such as the islet of Langerhans. However, the capacity of the glomerulosa cell to synthesize LO products and their role in aldosterone secretion is not known. To study this, the effect of nonselective and selective LO inhibitors on AII, ACTH, and potassium-induced aldosterone secretion and LO product formation was evaluated in isolated rat glomerulosa cells. BW755c, a nonselective $\mathrm{LO}$ inhibitor dose dependently reduced the AII-stimulated level of aldosterone without altering AII binding (91 \pm 6 to $36 \pm 4 \mathrm{ng} / 10^{6}$ cells $/ \mathrm{h} 10^{-4} \mathrm{M}, P$ $<0.001)$. The same effect was observed with another nonselective LO blocker, phenidone, and a more selective 12-LO inhibitor, Baicalein. In contrast U-60257, a selective 5-LO inhibitor did not change the AII-stimulated levels of aldosterone $\left(208 \pm 11 \%\right.$ control, AII $10^{-9} \mathrm{M}$ vs. $222 \pm 38 \%$, AII + U-60257). The LO blockers action was specific for AII since neither BW755c nor phenidone altered ACTH or $\mathrm{K}^{+}$-induced aldosterone secretion. AII stimulated the formation of the 12-LO product 12-hydroxyeicosatetraenoic acid (12-HETE) as measured by ultraviolet detection and HPLC in AA loaded cells and by a specific RIA in unlabeled cells (501 \pm 50 to $990 \pm 10 \mathrm{pg} / 10^{5}$ cells, $P<0.02$ ). BW755c prevented the AIImediated rise in 12-HETE formation. In contrast, neither ACTH nor $\mathrm{K}^{+}$increased 12-HETE levels. The addition of 12HETE or its unstable precursor 12-HPETE $\left(10^{-9}\right.$ or $\left.10^{-8} \mathrm{M}\right)$ completely restored AII action during LO blockade. AII also produced an increase in 15-HETE formation, but the 15-LO products had no effect on aldosterone secretion. These studies suggest that the 12-LO pathway plays a key role as a new specific mediator of AII-induced aldosterone secretion.
\end{abstract}

\section{Introduction}

Angiotensin II (AII), ${ }^{1}$ potassium $\left(\mathrm{K}^{+}\right)$, and $\mathrm{ACTH}$ are the major stimulators of aldosterone synthesis in vitro and in man

Address reprint requests to Dr. Stern, Section of Endocrinology/Medicine, Sepulveda VA Medical Center, 16111 Plummer Street, Sepulveda, CA 91343. Presented in part at the Endocrine Society Meeting, June 1986.

Received for publication 23 December 1986 and in revised form 27 April 1987.

1. Abbreviations used in this paper: AA, arachidonic acid; AII, angiotensin II; CO, cyclooxygenase; ETYA, eicosatetraynoic acid; LO, li-

J. Clin. Invest.

(c) The American Society for Clinical Investigation, Inc. 0021-9738/87/12/1763/07 \$2.00

Volume 80, December 1987, 1763-1769
(1-3) All three agonists activate the calcium messenger system, however, only AII induces the hydrolysis of phosphoinositides and releases intracellular calcium (4-6). After binding to its receptor, AII activates phospholipase $C$, which induces the formation of diacylglycerol and the release of arachidonic acid (AA) (7). The adrenal glomerulosa cell has been shown to metabolize AA via the cyclooxygenase $(\mathrm{CO})$ pathway to prostaglandins $E_{2}$ and $I_{2}(8-10)$. However, considerable evidence suggests that the CO pathway is not involved in basal or AIImediated aldosterone production (10-11).

Recent studies in rat pancreatic islets have shown that the lipoxygenase (LO) products of AA, such as 12 hydroperoxyeicosatetraenoic acid (12-HPETE) are important mediators of glucose-induced insulin secretion $(12,13)$. However, the capacity of the adrenal glomerulosa cell to synthesize LO products and their role in aldosterone synthesis is not known. We have evaluated the effect of AII, $\mathrm{K}^{+}$, and ACTH on LO product formation in isolated rat adrenal glomerulosa cells. In addition, we have studied the functional role of LO pathway activation with the use of selective $\mathrm{CO}$ and $\mathrm{LO}$ inhibitors. The results suggest that the 12-LO pathway plays a key role in mediating AII-induced aldosterone synthesis.

\section{Methods}

Preparation of isolated rat adrenal glomerulosa cells. The cells were freshly prepared using the method of Williams et al. (14). Male Sprague-Dawley rats (200-225 g) were decapitated and the adrenals removed and trimmed of fat and placed in normal saline. Capsules were separated by gross dissection and incubated with collagenase (3.7 $\mathrm{mg} / \mathrm{ml})$ and deoxyribonuclease $(0.05 \mathrm{mg} / \mathrm{ml})$ in a modified KrebsRinger bicarbonate buffer (KRBG) containing $4 \%$ bovine serum albumin (BSA, Pentex Fraction V, fatty acid free) essential and nonessential amino acids, L-glutamine and glucose for $50 \mathrm{~min}$ in a Dubnoff metabolic shaker under $95 \% \mathrm{O}_{2}, 5 \% \mathrm{CO}_{2}$. The cells were then mechanically separated by gentle pipetting and filtered through a gauze mesh. The suspension was spun at $100 \mathrm{~g}$ and washed three times with the KRBG and the glomerulosa cells were resuspended in the same buffer solution $\left(\mathrm{K}^{+} 3.7 \mathrm{meq} / \mathrm{liter}\right)$ to yield $\sim 150,000$ cells per $2 \mathrm{ml}$. The viability of the cells was $95 \%$ as determined using trypan blue exclusion.

Incubation of rat glomerulosa cells. The cell suspension in $2 \mathrm{ml}$ of KRBG buffer with $4 \%$ BSA was incubated in the presence or absence of the various test compounds in a metabolic shaker for $60 \mathrm{~min}$ at $37^{\circ} \mathrm{C}$ under a $95 \% \mathrm{O}_{2} / 5 \% \mathrm{CO}_{2}$ atmosphere. The cells were incubated with graded doses of AII, ACTH, or $\mathrm{K}^{+}\left(2 \times 10^{-11}\right.$ to $2 \times 10^{-8} \mathrm{M}, 1$ $\times 10^{-11}$ to $1 \times 10^{-8} \mathrm{M}$, and 3.7 to $10.7 \mathrm{meq} /$ liter, respectively) either alone or with various AA inhibitors. The inhibitors used were: BW755c (3 amino-m-trifluoromethyl-phenyl-2-pyrazoline $10^{-7}$, $-10^{-4} \mathrm{M}$, Burroughs Wellcome Co., Beckenham, Kent, UK) or phenidone $\left(10^{-4} \mathrm{M}\right.$, Sigma) both nonselective LO inhibitors, baicalein $\left(10^{-6}\right.$ M BioMol Research Laboratories, Philadelphia, PA) a more selective 12 LO inhibitor (15), meclofenamate $\left(10^{-3} \mathrm{M}\right.$, Sigma Chemical Co.,

poxygenase; $\mathrm{LTB}_{4}$, leukotriene $\mathrm{B}_{4}$; NDGA, nordihydroguaniaretic acid; 12-HPETE, 12 hydroperoxyeicosatetraenoic acid. 
St. Louis, MO), a specific CO inhibitor, and U60, 257 (16) $10^{-6} \mathrm{M}$ (Piriprost, Dr. Michael Bach, UpJohn Co., Kalamazoo, MI) a highly specific 5-LO inhibitor. To evaluate whether 12-HETE formation is via a cytochrome $\mathbf{P 4 5 0}$ epoxygenase enzyme we also used two structurally distinct cytochrome P450 inhibitors, metyrapone and SKF 525A (2-diethylaminoethyl-2, 2-diphenylvalerate hycrochloride; SmithKline \& French, Philadelphia, PA) at $6 \times 10^{-5} \mathrm{M}$ concentration.

To study the functional effects of $12-\mathrm{LO}$ products on basal aldosterone synthesis, the unstable product 12 -HPETE $\left(10^{-10}\right.$ to $10^{-7} \mathrm{M}$, BioMol Research Laboratories) or the more stable 12 hydroxyeicosatetraenoic acid (12-HETE $10^{-10}$ to $10^{-8} \mathrm{M}$ ), was added directly or with AII and BW755c to the cell suspension. Similarly, the 15 -LO products 15-HPETE and 15-HETE were also studied for their effects on aldosterone secretion.

The HPLC purified HPETEs and HETEs were added in $0.01 \%$ ethanol. Similar amounts of ethanol concentrations were added to the control incubations.

To test the capacity of rat adrenal cells to convert exogenous AA to HETEs in the basal state and after AII stimulation, highly purified AA (1 $\mu \mathrm{M}, 99 \%$ pure, Nu Chek Prep Co., Elysian, MN) was preincubated with glomerulosa cell suspensions in $2 \mathrm{ml}$ of BSA free KRBG buffer for $30 \mathrm{~min}$. After this incubation step, the cells were washed twice with KRBG containing 4\% BSA (fatty acid free, Pentex fraction V; Miles Laboratories, Naperville, IL) to remove all nonesterified AA. The incubations were then carried out as previously described for $60 \mathrm{~min}$ with no added agonist, AII alone $\left(10^{-9} \mathrm{M}\right)$ or AII plus BW755c $\left(10^{-4}\right.$ $M)$. An incubation of control medium with boiled cells was also performed to evaluate nonenzymatic oxidation of AA. At the end of the incubation period the reaction was stopped by adding $2 \mathrm{ml}$ of $100 \%$ ethanol.

${ }^{125}$ I-Angiotensin II binding. ${ }^{125} \mathrm{I}$-AII binding assays were performed as previously described (17) with minor modifications. Freshly obtained adrenal capsules from seven to eight rats per assay were homogenized with a Teflon glass homogenizer in a buffer containing $0.25 \mathrm{M}$ sucrose, $1 \mathrm{mM}$ EDTA and $10 \mathrm{mM}$ Tris $\left(\mathrm{pH} 7.4,4^{\circ} \mathrm{C}\right)$. The homogenate was centrifuged at $1500 \mathrm{~g}$ for $10 \mathrm{~min}$. The supernate was then spun at 20,000 for $30 \mathrm{~min}$ and the pellet washed twice in the incubation buffer containing $120 \mathrm{mM} \mathrm{NaCl}, 1 \mathrm{mM}$ EDTA, $5 \mathrm{mM}$ dithiothreitol, $2 \mathrm{mM} \mathrm{MgCl}, 0.2 \% \mathrm{BSA}$, and $50 \mathrm{mM}$ Tris ( $\mathrm{pH} 7.4$ ). The pellet was then resuspended in the incubation buffer to yield a protein concentration of $240-300 \mu \mathrm{g} / \mathrm{ml}$. ${ }^{125} \mathrm{I}-\mathrm{AII}$ (New England Nuclear, Boston, MA; specific activity $1,880 \mu \mathrm{Ci} / \mu \mathrm{g}) 150,000 \mathrm{dpm}$ was incubated in triplicate with various concentrations of unlabeled AII $\left(3 \times 10^{-10}-10^{-6}\right.$ $M)$. For each concentration triplicate tubes in a final volume of $0.5 \mathrm{ml}$ were incubated for $45 \mathrm{~min}$ at $22^{\circ} \mathrm{C}$. Bound and free ligand were separated by Milipore filtration using buffer presoaked glass fiber GF/C filters (Whatman Inc., Clifton, NJ). Filters were counted in a gamma counter (Gamma 4000; Beckman Instruments, Inc., Fullerton, CA). Nonspecific binding defined as filter bound labeled ligand in the presence of $10^{-6} \mathrm{M}$ unlabeled AII was $6 \pm 1 \%$ of the total binding. Protein concentration was determined by method of Lowry.

\section{Measurement of HETEs}

Extraction. After precipitation of cell proteins in $100 \%$ ethanol and removal of buffer and solvent under nitrogen, the sample was redissolved in $15 \%$ ethanol and water, acidified to $\mathrm{pH} 4.0$ with hydrochloric acid $\left(1 \mathrm{~N}\right.$ ) and transferred to a octadecasilyl $\mathrm{C}_{18}$ mini column (SEPPAK, Waters Associates, Milford MA) that has been prewashed successively in $20 \mathrm{ml}$ methanol and $20 \mathrm{ml}$ water. The elution of HETEs was done using a modification of the method of Powell (18). The column was successively washed with $15 \%$ ethanol and water $(20 \mathrm{ml})$, water $(20 \mathrm{ml})$, petroleum ether $(6 \mathrm{ml})$ and the compounds of interest eluted with ethyl acetate $(15 \mathrm{ml})$. All solvents were of HPLC quality (Burdick and Jackson Laboratories, Inc., Muskegan, MI). The ethyl acetate fraction was then filtered through a nylon 66 disk filter. By adding known amounts of labeled standards prior to extraction, recovery was calculated to be $88 \pm 2 \%$ (SE) for 12 -HETE. Similar recoveries were found for 5 and 15 HETE.
HPLC. The extracted sample in ethyl acetate was dried under nitrogen and redissolved in $100 \mu \mathrm{l}$ of $100 \%$ methanol. This sample was then injected into a series 4 HPLC (Perkin-Elmer Co., Norwalk, CT) equipped with a $\mathrm{C} 18$ column (Perkin-Elmer 3 micron, $10 \mathrm{~cm}$ length) and a LC-85 UV detector. The solvent mixture is a combination of an isocratic and gradient elution program modified from the method of Peters et al. (19); solvent A (0.01\% acetic acid, pH 3.7), solvent B (acetonitrile), and solvent $\mathrm{C}$ (methanol). The initial solvent mixture was isocratic in $67 \%$ solvent $A$ and $33 \%$ solvent $B$ at $1 \mathrm{ml} / \mathrm{min}$ for 6 min. A convex gradient over $8 \mathrm{~min}$ then went to $10 \% \mathrm{~A}, 80 \% \mathrm{~B}, 10 \% \mathrm{C}$. At $14 \mathrm{~min}$ a wash with $100 \%$ B began and continued for $4 \mathrm{~min}$. The system was then regenerated to the initial solvent ratio with a linear gradient over $4 \mathrm{~min}$. With this technique any prostaglandins (PGs) and leukotrienes in the sample are eluted before $5 \mathrm{~min}$. The HETEs or HPETEs elute between 10 and $12 \mathrm{~min}$, while unreacted AA elutes at $14.0 \mathrm{~min}$. The sensitivity of this system for detection of the HETEs is 1 ng at $235 \mathrm{nM}$. The recovery of added ${ }^{3} \mathrm{H}$ 5-, 12- or 15-HETE (New England Nuclear) taken through the entire process of deproteinization, extraction, and HPLC with collection of the appropriate fraction in a Frac 100 fraction collector (Pharmacia Fine Chemicals, Uppsala Sweden) is $74 \pm 2 \%$ (SE, $n=20$ ).

To confirm the presence of 12-HETE and to better separate 12HETE from other LO products we also used a reverse phase HPLC system with a Shandon $25 \mathrm{CM}$ high resolution 3-micron column (Keystone Scientific, State College, PA) using a gradient elution program with solvent $A(0.01 \%$ acetic acid, ph 3.7$)$, solvent $B$ (acetonitrite), and solvent $\mathrm{C}$ (methanol). The initial solvent mixture is $33 \% \mathrm{~A}, 10 \% \mathrm{~B}$, $57 \% \mathrm{C}$ which then went to $10 \% \mathrm{~A}, 10 \% \mathrm{~B}$, and $80 \% \mathrm{C}$ over $20 \mathrm{~min}$. Then at $20 \mathrm{~min}$ a wash begins with $10 \% \mathrm{~B}$ and $90 \% \mathrm{C}$ for $5 \mathrm{~min}$. In this system the sensitivity for 12-HETE is $1 \mathrm{ng}$ at $235 \mathrm{nM}$. 12-HETE elutes at $16.8 \mathrm{~min}$, whereas 15 -HETE elutes at $15.2 \mathrm{~min}$.

Radioimmunoassay of 12 and 15-HETE. Since cells produce too little endogenous HETE to be reliably seen by UV detection, a specific RIA technique was used to quantify endogenous 12-HETE formed in the basal state and after agonist stimulation. We used the specific antisera provided by Advanced Magnetics, Inc. (Boston, MA) in a working titer of $2 \times 10^{3}$ dilution giving a $B_{0}$ of $54 \%$. The cross-reactivity of this antiserum is: 12(S)-HETE $100 \%, 12$ (R)-HETE $<0.01 \%$, 15-HETE 0.3\%, 5 HETE $0.2 \%$, thromboxane $\mathrm{B}_{2}\left(\mathrm{TXB}_{2}\right)<0.1 \%$, $\mathrm{PGE}_{2}$ $0.1 \%, 6$ keto prostacycline $1 \alpha(\mathrm{PGF} 1 \alpha) 0.1 \%$, leukotriene $\mathrm{B}_{4}\left(\mathrm{LTB}_{4}\right)$ $0.1 \%$, arachidonic acid $0.1 \%, 8,15$ and 5,15 diHETE $0.1 \%$ and 8,9 , and 11 -HETE; all $<0.01 \%$. For the assay $100 \mu$ l of the appropriate dried fraction was incubated with antibody $(100 \mu \mathrm{l})$ and authentic $\left[{ }^{3} \mathrm{H}\right] 12$ HETE tracer $(4,000 \mathrm{cpm}$, New England Nuclear) in a phosphate buffer solution, $\mathrm{pH} 8.5$ overnight at $4^{\circ} \mathrm{C}$. Separation of bound from free was achieved by the addition of $700 \mu l$ of dextran-coated charcoal. Nonspecific binding is $<6 \%$ with an assay blank of $8 \mathrm{pg} / \mathrm{ml}$. The sensitivity of the method is $10 \mathrm{pg} / \mathrm{ml}$ with an intraassay variation of $8 \%$. All control and experimental samples were run in the same assay. Validation procedures included the assay of known added amounts of standard and variable amounts of extract $(r=0.95)$. In addition, sample values gave an excellent correlation $(r=0.91 ; P<0.01)$ when assayed using the well characterized independent 12-HETE antisera kindly provided by Dr. L. Levine, Brandeis University (20). All samples for the RIA were stored in the dark under nitrogen at $-70^{\circ} \mathrm{C}$ until assay. 15-HETE was assayed using specific antisera provided by Advanced Magnetics Inc., in a working titer of 1:700 with binding at Bo of $56 \%$. It has low cross-reactivity: 5-HETE $0.1 \%, 12$-HETE $0.5 \%, 5,15$ diHETE 1\%, 8,15 diHETE $1 \%$, arachidonic acid, $\mathrm{PGB}_{2}, \mathrm{PGE}_{2}, \mathrm{PGF}_{1}, \mathrm{TXB}_{2}$, all $0.1 \%$. The assay used authentic $\left[{ }^{3} \mathrm{H}\right] 15-\mathrm{HETE}$ tracer $(4000 \mathrm{cpm})$. The assay technique is the same as for the 12-HETE method. Nonspecific binding is $<7 \%$ with an assay blank of $6 \mathrm{pg} / \mathrm{ml}$. The sensitivity is $10 \mathrm{pg} / \mathrm{ml}$ with an interassay variation of $10 \%$. All control and experimental samples are run in the same assay. Assay of known amounts of standard gives an excellent correlation with calculated $(r=0.92)$.

Aldosterone measurement. At the conclusion of each incubation a $200-\mu \mathrm{l}$ aliquot of the cell suspension was removed and extracted with methylene chloride (1:15 vol/vol) and assayed for aldosterone by RIA 
using a highly specific antibody obtained from Endocrine Sciences (Tarzana, CA). Cross-reactivity of this antisera with corticosterone, deoxycorticosterone, 18 hydroxycorticosterone, progesterone, 17-OH progesterone is $<0.01 \%$. This assay technique correlated well with a previously described method using chromatography $(r=0.99$, slope $=0.98, n=55)(21)$.

Corticosterone levels were measured by RIA with a highly specific antibody supplied by Endocrine Sciences.

Data analysis. To compare basal with experimental values for aldosterone and 12-HETE a Student's $t$ test was used for nonpaired values. Data analysis was performed on a CLINFO Computer System (GCRC RR-43). Binding data was analyzed using a version of LIGAND adopted for an Apple IIe computer.

\section{Results}

Effect of LO inhibition on aldosterone synthesis. The nonselective LO inhibitor, BW755c $\left(10^{-4} \mathrm{M}\right)$ markedly reduced the AII-stimulated secretion of aldosterone (Fig. 1 a). BW755c decreased the overall mean maximal AII stimulated aldosterone secretion from $91 \pm 6$ to $36 \pm 4 \mathrm{ng} / 10^{6}$ cell per $\mathrm{h}(n=12, P$ $<0.001)$. Similarly BW755c reduced AIl-mediated secretion of corticosterone $\left(4.6 \pm 0.06\right.$ to $2.8 \pm 0.4 \mu \mathrm{g} / 10^{6}$ cells per $\mathrm{h}, n$ $=3, P<0.002$ ) while the secretion rate was not significantly different than baseline $\left(2.6 \pm 0.02 \mu \mathrm{g} / 10^{6}\right.$ cells $)$. The inhibitory effect was dose dependent with significant reduction of AII-induced aldosterone synthesis by concentrations of BW755c starting at $10^{-7} \mathrm{M}$ (Fig. $1 \mathrm{~b}$ ). In several experiments $(7 / 12)$ BW755c at $10^{-4} \mathrm{M}$ also reduced basal aldosterone secretion ( $42 \pm 5$ to $30 \pm 3 \mathrm{ng} / 10^{6}$ cells per $\mathrm{h}, n=7, P<0.01$ ). In contrast, BW755c did not alter the sensitivity or peak secretion rate of aldosterone incubated with graded doses of ACTH (Fig. 2) or $\mathrm{K}^{+}$(Fig. 3). Another LO inhibitor, phenidone $\left(10^{-4} \mathrm{M}\right)$ significantly reduced AII-stimulated aldosterone secretion $(29 \pm 1$ basal to $67 \pm 2$ AII $10^{-9} \mathrm{M}$ vs. $50 \pm 2 \mathrm{ng} / 10^{6}$ cells/hour AII + phenidone $n=6, P<0.05$ vs. AII alone). However, pheni-
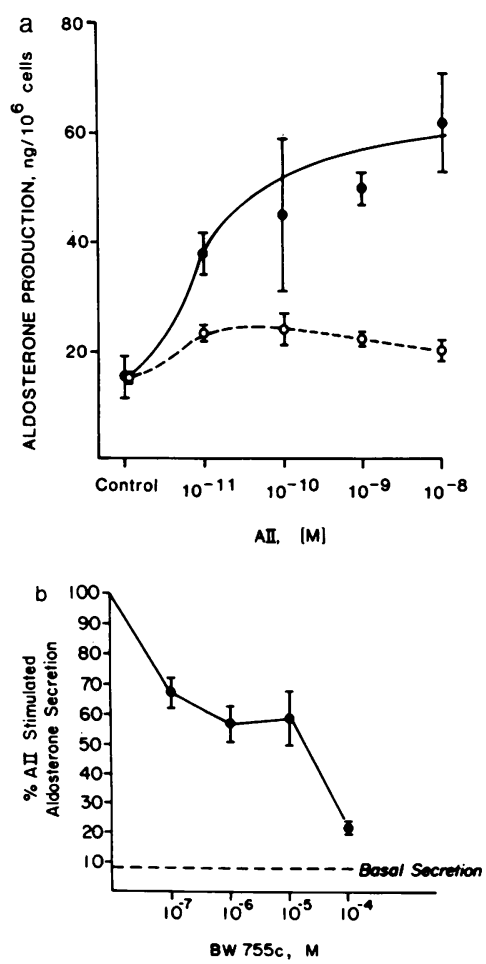

Figure 1. (a) Angiotensin II (AII) stimulated aldosterone secretion in the absence $(-0-)$ and presence of the lipoxygenase inhibitor BW755c $\left(10^{-4} \mathrm{M}\right)$ (--- $0---)$. Results are the mean \pm SE or triplicate determinations $(n=3)$ in 1 of 12 such experiments. $(b)$ Effect of incremental concentration of BW755c on AII $\left(10^{-9} \mathrm{M}\right)$ mediated aldosterone secretion. Results are expressed as mean percent \pm SEM of AII-stimulated aldosterone levels ( $n$ $=6$ ), from two separate experiments. Dotted line represents basal aldosterone secretion $\left(0.8 \pm 0.1 \mathrm{ng} / 10^{6}\right.$ cells per $h$ ). All in the absence of inhibitor produced levels of aldosterone at $8.3 \pm 0.3 \mathrm{ng} / 10^{6}$ cells per $\mathrm{h}$.

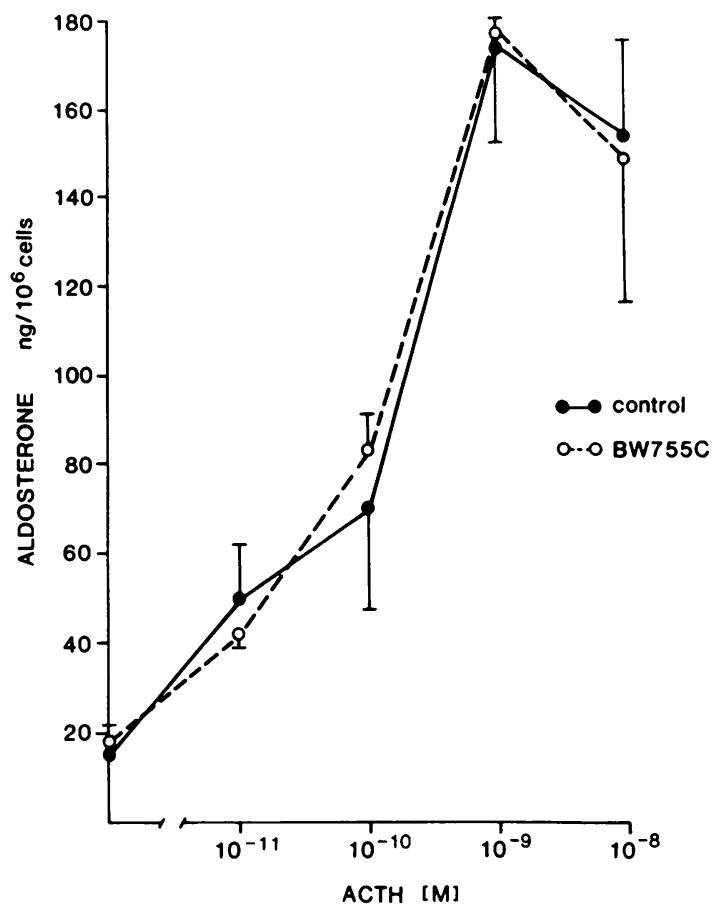

Figure 2. Effect of ACTH on aldosterone secretion in the absence and presence of BW755c $\left(10^{-4} \mathrm{M}\right)$. Results are the mean \pm SE of triplicate determinations $(n=3)$ in one of three similar experiments.

done did not alter $\mathrm{K}^{+}$induced aldosterone release (105 \pm 12 vs. $87 \pm 11 \mathrm{ng} / 10^{6}$ cells per $\mathrm{h}, 5.7 \mathrm{meq}$ and $109 \pm 18$ vs. $104 \pm 17,8.7$ meq, $n=6, P=\mathrm{NS}$ for $\mathrm{K}^{+}$alone vs. $\mathrm{K}^{+}+$phenidone, respectively).

Since BW755c can also block the CO pathway, a selective $\mathrm{CO}$ blocker meclofenamate was studied to determine whether the effects of BW755c were due to $\mathrm{CO}$ inhibition. However, as shown in Table $I$, even a high concentration of meclofenamate $\left(10^{-3} \mathrm{M}\right)$ did not prevent AII-induced aldosterone synthesis.

Baicalein, a more selective 12-LO inhibitor with little CO inhibitory effects was also studied. This more specific agent also reduced AII-mediated aldosterone secretion ( $10 \pm 0.5$ basal
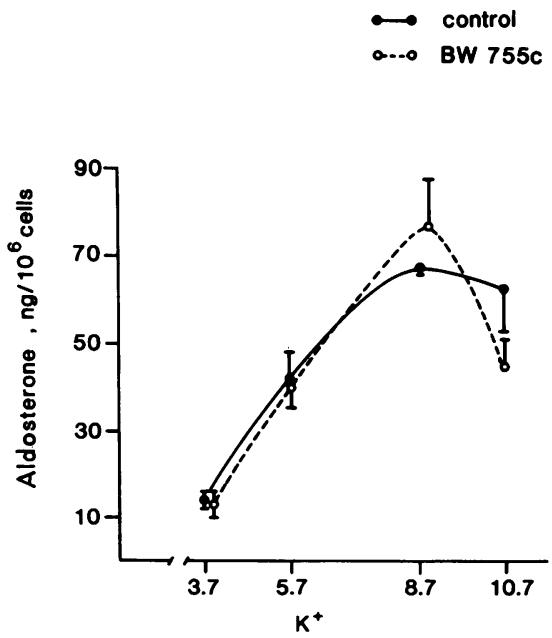

Figure 3. Effect of potassium $\left(\mathrm{K}^{+}\right.$, millimoles per liter) on aldosterone synthesis in the absence or presence of BW755c $\left(10^{-4} \mathrm{M}\right)$. Results are the mean $\pm \mathrm{SE}$ of triplicate determinations $(n=3)$ in one of three similar experiments. 
Table I. Effects of Meclofenamate and U60257 on AII-stimulated Aldosterone Secretion

\begin{tabular}{lcll}
\hline & Control & Meclofenamate & U60257 \\
\hline & & $10^{-3} M$ & $10^{-5} M$ \\
KRBG alone & $98 \pm 8$ & $100 \pm 16 \%$ & $100 \pm 8 \%$ \\
AII, $10^{-9} \mathrm{M}$ & $208 \pm 11 \%^{*}$ & $210 \pm 10 \%^{*}$ & $222 \pm 38 \%^{*}$ \\
AII, $10^{-8} \mathrm{M}$ & $255 \pm 15 \%^{*}$ & $287 \pm 48 \%^{*}$ & $232 \pm 15 \%^{*}$ \\
\hline
\end{tabular}

Results are in percentage of basal as the mean \pm SEM of six to nine determinations from two to three separate experiments. Basal secretion was $21 \pm 2 \mathrm{ng} / 10^{6}$ cells $/ \mathrm{h}$.

$* P<0.01$

vs. $32 \pm 2 \mathrm{ng} / 10^{6}$ cells per h AII $10^{-9} \mathrm{M}$ vs. $20 \pm 2$ AII + baicalein $10^{-6} \mathrm{M}, n=6, P<0.02$ AII vs. AII + baicalein). The steroidogenic inhibitory actions were also associated with a reduction in 12-HETE formation $(120 \pm 2 \%$ control AII vs. $78 \pm 5 \%$ AII + baicalein, $P<0.01$ ).

To examine the role of the 5-LO pathway in AII action, a selective 5-LO inhibitor U60, 257 was studied. As shown in Table I, this highly selective 5-LO inhibitor did not attenuate AII stimulatory effects on aldosterone synthesis, suggesting that BW755c, phenidone, and baicalein are not acting via 5-LO inhibition to block AII effects.

Effect of LO inhibition on ${ }^{125}$ I-AII binding to glomerulosa membranes. Since LO inhibition selectively blocked AII mediated aldosterone synthesis, the effect of the LO inhibitor BW755c on AII binding to glomerulosa cell membranes was studied. Mean AII receptor concentration was similar in control membranes and in those co-incubated with BW755c, respectively, $[1,170 \pm 74 \mathrm{fmol} / \mathrm{mg}$ protein $(n=5)$ and $1,220 \pm 60$, $n=2$ ]. Similarly, BW755c did not alter receptor affinity $\left(K_{\mathrm{a}}\right)$, $\left(1.50 \pm 0.2 \times 10^{9} \mathrm{M}^{-1}\right.$ and $1.75 \pm 0.2 \times 10^{9} \mathrm{M}^{-1}$ control and BW755c treated membranes, respectively).

Effect of AII, ACTH, and $\mathrm{K}^{+}$on HETE formation. AII $\left(10^{-9} \mathrm{M}\right)$ stimulated the formation of immunoreactive 12 HETE (Fig. 4) $\left(501 \pm 50\right.$ to $990 \pm 10 \mathrm{pg} / 10^{5}$ cells $\left.P<0.02\right)$. In addition, BW755c reduced the stimulated level back to the control level (Fig. 4). AII also slightly stimulated immunoreactive 15 -HETE levels $\left(756 \pm 80\right.$ to $1,050 \pm 90 \mathrm{pg} / 10^{5}$ cells, $n=4$, $P<0.05$ ). Similarly, in cells prelabeled with $99 \%$ pure AA, AII stimulated predominately 12 -HETE as revealed by ultraviolet detection at $235 \mathrm{nM}$ in a sensitive reverse-phase HPLC system (Fig. 5, $a-c$ ). The peak heights shown at the same attenuation setting reveal the marked stimulation of peaks co-migrating with 12-HETE and to a lesser extent 15-HETE. This was also confirmed by comigration with the authentic $\left[{ }^{3} \mathrm{H}\right] 12$-HETE and $\left[{ }^{3} \mathrm{H}\right] 15$-HETE in the same sample. Both the 12 and 15 HETE peaks showed an ultraviolet maximum at $235 \mathrm{nM}$. The addition of BW755c to the incubation greatly reduced the

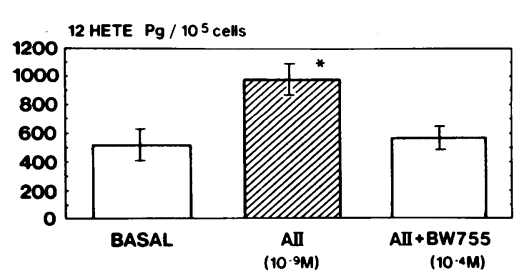

Figure 4. Effect of AII $\left(10^{-9} \mathrm{M}\right)$ alone and AII + BW755c $\left(10^{-4} \mathrm{M}\right)$ on immunoreactive 12HETE release. Mean \pm SE shown.* $n$ $=8 ; P<0.02$ vs. basal or AII + BW755c.
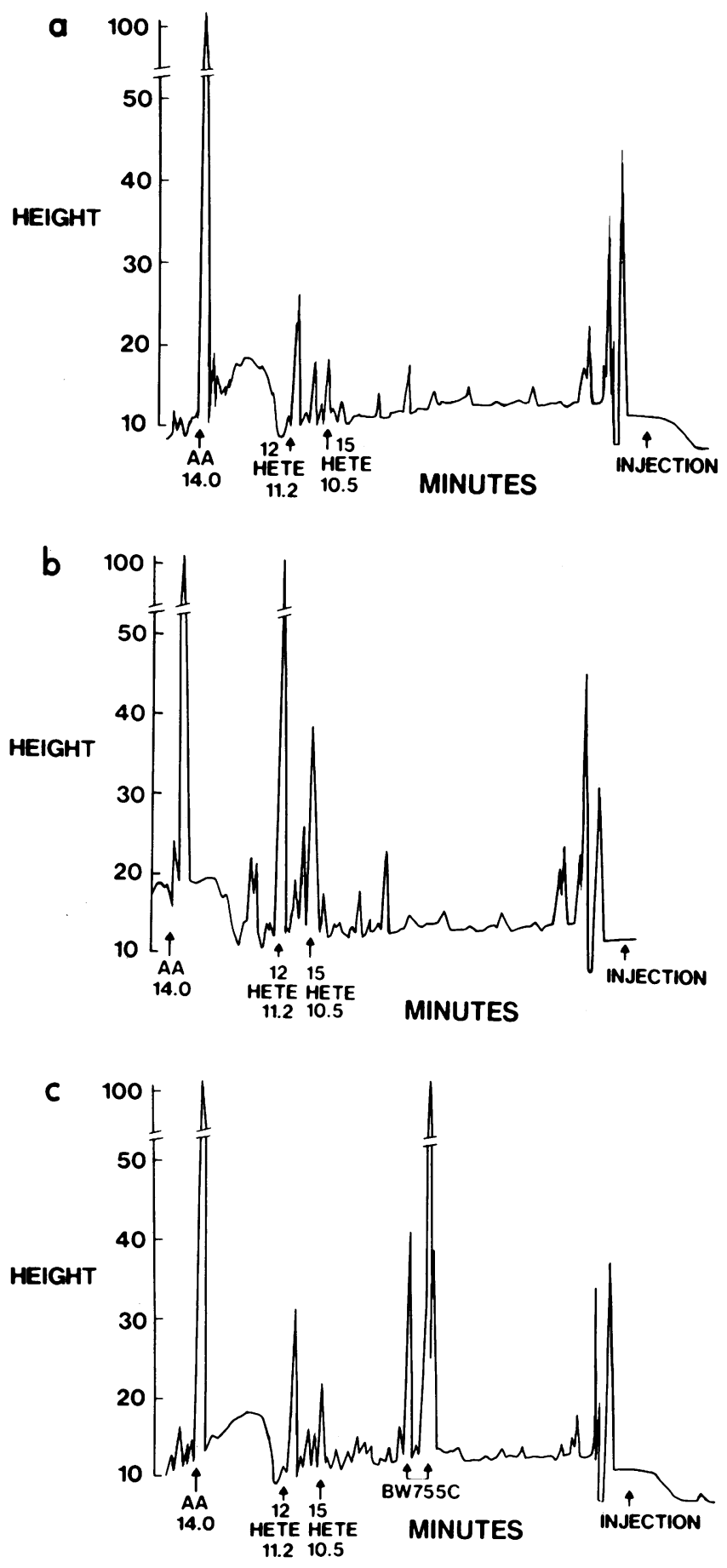

Figure 5. Reverse phase HPLC tracing of glomerulosa cells incubated with $>99 \%$ pure AA. Wavelength setting for UV detection is 235 $\mathrm{nM}$. All attenuation settings are 0.08 full scale. Arrows indicate point of sample injection and retention times of peaks, comigrating with authentic HETE standards and AA. Peak heights are shown in a relative scale from 0-100: (a) Basal glomerulosa cell incubate; $(b)$ Incubate from same experiment during addition of AII $\left(10^{-9} \mathrm{M}\right)$; and $(c)$ Incubate from the same experiment during addition of AII with BW755c $\left(10^{-4} \mathrm{M}\right)$

peak heights corresponding to the HETES and gave heights of 12 and 15 HETE similar to the basal (Fig. $5 c$ ). AA alone (not shown) incubated with medium alone or boiled cells gave no major peaks in the region of 12-HETE or 15-HETE suggesting 
Table II. Effect of $A C T H$ and $K^{+}$on Immunoreactive 12-HETE Formation

\begin{tabular}{|c|c|c|c|c|c|}
\hline & \multirow[b]{3}{*}{ Control } & \multicolumn{4}{|c|}{ Incubation condition } \\
\hline & & \multicolumn{2}{|l|}{ АCTH } & \multicolumn{2}{|l|}{$\mathrm{K}^{+}$} \\
\hline & & $10^{-8}$ & $10^{-9}$ & 5.7 & 8.7 \\
\hline & & $M$ & $M$ & meq/liter & meq/liter \\
\hline $\begin{array}{l}\text { 12-HETE } \\
\text { (\% control) }\end{array}$ & $100 \pm 10(6)$ & $78 \pm 13^{*}(5)$ & $90 \pm 15(5)$ & $72 \pm 11^{*}(3)$ & $72 \pm 12 *(3)$ \\
\hline
\end{tabular}

Values are shown as percent of control (mean $\pm \mathrm{SD}$ ).

* $P<0.01$ vs. control values using a nonpaired $t$ test adjusted for unequal variance using a CLINFO computer system. Parentheses include the number of observations.

no major nonenzymatic conversion of AA to 12 or 15-HETE. In contrast, $\mathrm{ACTH}$ and $\mathrm{K}^{+}$did not stimulate the formation of immunoreactive 12-HETE. Surprisingly, these agents tended to lower 12-HETE levels compared with the control (Table II).

To evaluate whether 12-HETE formation is via a cytochrome $\mathrm{P} 450$ epoxygenase enzyme, the effect of metyrapone and SKF525A on 12-HETE formation was studied. At 5 $\times 10^{-5} \mathrm{M}$ concentration metyrapone and SKF525A similarly reduced aldosterone secretion $(1.4 \pm 3$ to $0.4 \pm 0.1$ and $0.46 \pm 0.1$ $\mathrm{ng} / 10^{6}$ cells per $\mathrm{h}$, respectively, $n=4, P<0.01$ ). However, neither inhibitor altered 12-HETE levels (517 \pm 41 basal vs. $651 \pm 37$ vs. $739 \pm 89 \mathrm{pg} / 10^{5}$ cells, respectively, $n=4, P>0.1$ ).

Effect of 12 and 15 LO products on aldosterone secretion. To further evaluate the functional role of the 12-LO pathway for AII action, the effect of 12-HETE and its unstable precursor 12-HPETE on restoring AII stimulation of aldosterone during BW755c treatment was studied. 12-HETE in concentrations as low as $10^{-10} \mathrm{M}$ partially restored AII action, while concentrations of $10^{-8}$ and $10^{-9} \mathrm{M}$ completely restored the stimulatory effects of AII during LO blockade (Fig. 6). Simi-
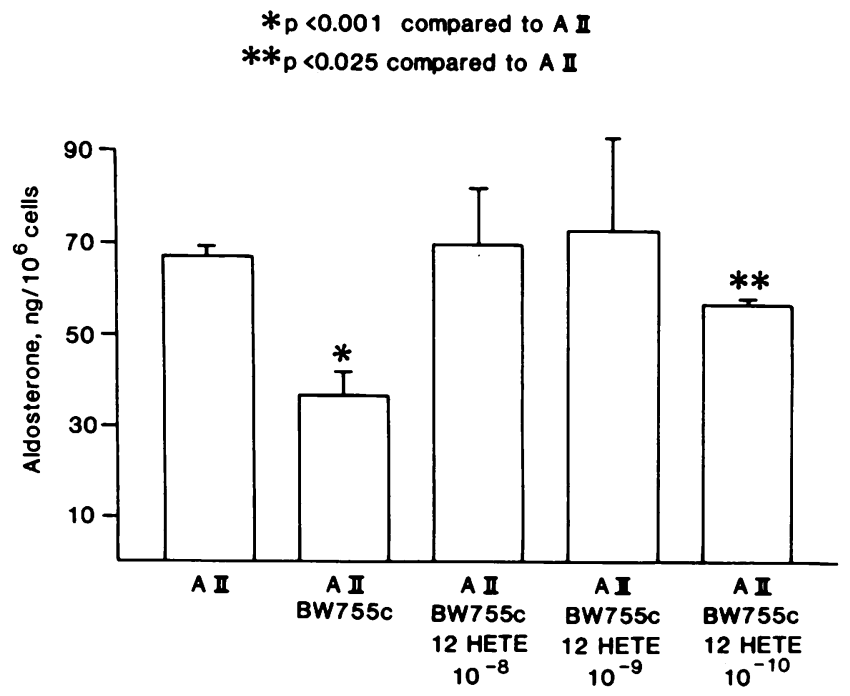

Figure 6. Effect of 12-HETE $\left(10^{-10}\right.$ to $\left.10^{-8} \mathrm{M}\right)$ on aldosterone secretion in the presence of AII $\left(10^{-9} \mathrm{M}\right)$ and BW755c $\left(10^{-4} \mathrm{M}\right)$. Results are mean \pm SEM of triplicate determination $(n=3)$ in one of two similar experiments. 12-HETE at $10^{-8}$ and $10^{-9} \mathrm{M}$ completely restored AII stimulatory effects on aldosterone secretion during BW755c addition. larly, 12-HPETE $\left(10^{-8} \mathrm{M}\right)$ restored the AII-mediated aldosterone levels $\left(240 \pm 20 \%\right.$ basal, AII $10^{-9} \mathrm{M}$ alone vs. $95 \pm 19 \%$, AII + BW755c vs. $210 \pm 46 \%$, AII + BW755c + 12-HPETE). 12 HPETE also directly stimulated aldosterone secretion $\left(100 \pm 5 \%\right.$ basal to $133 \pm 8 \%, 10^{-9} \mathrm{M}, n=6, P<0.02$ and $163 \pm 11 \% 10^{-8} \mathrm{M}, n=6, P<0.01$ vs. basal). In marked contrast, neither 15-HETE nor 15-HPETE altered aldosterone secretion ( $100 \pm 6 \%$ basal vs. $107 \pm 11,15$ HETE, $10^{-8} \mathrm{M}$ and $120 \pm 8 \% 10^{-8} \mathrm{M}, 15$-HPETE both $P<0.3, n=6$ ).

\section{Discussion}

Increasing evidence suggests that AII in adrenal glomerulosa cells and in isolated vascular smooth muscle activates phospholipase $\mathrm{C}$, resulting in the formation of inositol phosphates and diacylglycerides $(4,22-24)$. Although, the turnover of inositol phosphate is rapid and transient, recent studies indicate a longer, more sustained formation of diacylglycerol that may explain the sustained action of AII despite the return of intracellular $\mathrm{Ca}^{2+}$ to basal levels $(4,24)$. Despite the evidence that diacylglycerol is rich in AA and AII can increase the release of AA in adrenal glomerulosa cells, the precise role of this fatty acid and its derived products in steroidogenesis has not been clarified.

Previous studies have shown that the adrenal glomerulosa can synthesize $\mathrm{CO}$ products of $\mathrm{AA}$ such as $\mathrm{PGI}_{2}$ and $\mathrm{PGE}_{2}$ (8-11). However, considerable evidence suggests that these PGs do not play a role in steroidogenesis since most studies indicate that $\mathrm{AII}, \mathrm{ACTH}$, and $\mathrm{K}^{+}$do not stimulate their formation, nor do $\mathrm{CO}$ blockers prevent AII-induced aldosterone synthesis $(8,11,25,26)$. Several reports have shown that indomethacin can alter aldosterone synthesis $(10,27,28)$. However, this has not been a consistent finding $(8,11,25,26)$ and the current study as well as others using other more specific $\mathrm{CO}$ blockers such as meclofenamate and U-51605 show no inhibition of AII induced aldosterone formation (9, 28, 29). This suggests that indomethacin has nonspecific effects which can alter steroidogenesis.

The current investigation is the first study to show that isolated adrenal glomerulosa cells produce LO products from both endogenous and exogenously derived AA. The major product formed, 12-HETE, was detected using two independent methods, UV detection during HPLC and a specific RIA. The results suggest that 12-LO activation may be a key step in AII-induced aldosterone synthesis. This is supported by several observations including: (a) AII, but not ACTH or $\mathrm{K}^{+}$ stimulates 12-HETE formation; $(b)$ three distinct LO inhibitors that prevent 12-HETE formation selectively block AII induced aldosterone synthesis; $(c)$ The inhibitory effects of LO antagonists are not via interference with AII binding to its receptor; and $(d)$ The addition of 12-HETE and 12-HPETE restores the AII stimulatory effects during LO inhibition.

In this study two nonselective LO inhibitors, BW755c and phenidone, and a more selective 12-LO inhibitor baicalein blocked AII-induced aldosterone formation. We did not use several other reported LO inhibitors such as nordihydroguaniaretic acid (NDGA) and eicosatetraenoic acid since these agents, unlike BW755c, have potent effects on guanylate cyclase (30). In addition NDGA and ETYA can nonspecifically alter contractile responses independent of effects on LO enzyme inhibition (31). Also, NDGA at lower doses is a more 
potent inhibitor of 5-LO activity (32). BW755c did not appear to be toxic based on the normal appearance of the cells, the dose-dependent inhibitory actions on AII and its lack of effect on $\mathrm{K}^{+}$and ACTH-induced aldosterone release. Similarly, BW755c did not appear to be acting as a $\mathrm{Ca}^{2+}$ channel blocker since $\mathrm{K}^{+}$induced aldosterone formation was not altered. This is also supported by the study by Rasmussen and co-workers who showed that BW755c prevented AII-induced aldosterone formation without altering AII mediated $\mathrm{Ca}^{45}$ flux (26).

In contrast to the effect of BW755c, phenidone, and baicalein, a specific 5-LO inhibitor U-60257 at doses that have been shown to markedly inhibit 5-LO activation (16) in other cell types, did not prevent AII-induced aldosterone production. These results suggest that the 12 and not the 5-LO pathway is involved in AII-mediated steroidogenesis.

15-HETE is also synthesized in the glomerulosa cells in the basal state and in response to AII. However, the magnitude of 15-HETE stimulation by AII is less than for 12-HETE and neither 15-HPETE nor 15-HETE alter aldosterone synthesis. This suggests that the 15-LO pathway is not primarily involved in AII-mediated steroidogenesis. However, additional studies will be required to determine whether 15-HETE is involved in other actions of AII, such as glomerulosa cell mitogenic activity and growth.

The glomerulosa cell preparation used in the current study may be contaminated with up to $5 \%$ fasiculata cells. However, recent evidence suggests that isolated rat fasiculata cells do not synthesize 12-HETE but only the 5-LO derived products such as 5-HETE and $\mathrm{LTB}_{4}$ (33). In addition, in the rat one would not expect a fasiculata-derived product to be stimulated by AII. Therefore, the source of 12-HETE is most likely from 12-HPETE synthesized by the glomerulosa cells.

The mechanism of 12-LO pathway mediated aldosterone synthesis cannot be determined from this study. Since LO blockade diminishes both the aldosterone and corticosterone response to AII, the effect appears to modulate the early pathway of aldosterone synthesis. Some evidence suggests that several AA metabolites including the HETEs can activate protein kinase $C$ (34), while other studies show that 12-HETE can induce vascular smooth muscle migration via changes in $\mathrm{Ca}^{2+}$ flux (35). A very recent study also suggests that AA itself in $\mathrm{Ca}^{2+}$ free media can increase intracellular $\mathrm{Ca}^{2+}$ levels in rat islets of Langerhans (36). Additional studies using specific inhibitors of the protein kinase $\mathrm{C}$ and $\mathrm{Ca}^{2+}$ messenger systems will be needed to clarify these effects. However, since diacylglycerol is potentially a major source of AA for LO activation, 12-LO products formed most likely function to maintain aldosterone synthesis during the sustained phase of action of AII. This is supported by the recent study showing that in a perifusion system BW755c inhibits AII-induced aldosterone synthesis only after $20 \mathrm{~min}(26)$.

Increasing evidence suggests that metabolism of AA via the LO or cytochrome P-450 epoxygenase pathway may produce important mediators of stimulus-secretion coupling in endocrine tissues such as the pituitary (37-39), gonad (40), and pancreatic islet $(12,13,41)$. The current results now suggest that AA conversion to products of the 12-LO pathway is a key step in AII induced action in the adrenal gland. Our results showing no inhibition of 12-HETE with two structurally distinct cytochrome P450 inhibitors suggests that 12-HETE formation in the rat adrenal glomerulosa cell is not via the P450 epoxygenase system described by others in the kidney and liver (42-44). However, additional studies will be needed to fully clarify whether other AA metabolites such as epoxides play any role in aldosterone synthesis.

In summary, in isolated glomerulosa cells, AII predominately stimulates the formation of the 12 -LO product, 12HETE, which functions as an important mediator of AII induced aldosterone formation. The synthesis of 12-HETE is specifically linked to AII, since neither $\mathrm{K}^{+}$or ACTH enhance 12-HETE formation. Since AII is a major regulator of both aldosterone synthesis and vascular smooth muscle tone, these results may form the basis for a new understanding of pathological states in man associated with altered levels or action of angiotensin II.

\section{Acknowledgments}

The authors thank Ms. Denise Walters for preparation of the manuscript and S. Goodson and Gerard Jensen for their technical assistance. In addition we thank S. Moncada of the Burroughs Wellcome Co. for BW755C and M. Bach of Upjohn for U60, 257.

This research was supported in part by the American Heart Association, Los Angeles Affiliate (841 Gi-1 and $831 \mathrm{Gl}-1$ ) and the Veterans Administration (Dr. Stern). Dr. Nadler is the recipient of NIH Clinical Investigator Award HLO1496.

\section{References}

1. Haning, R., S. A. S. Tait, and J. F. Tait. 1970. In vitro effects of ACTH, angiotensins, serotonin and potassium on steroid output and conversion of corticosterone to aldosterone by isolated adrenal cells. Endocrinology. 87:1147-1167.

2. Horton, R. 1969. Stimulation and suppression of aldosterone in plasma of normal men and in primary aldosterone. J. Clin. Invest. 48:1230-1236.

3. Kaplan, N. M., and F. C. Bartter. 1962. The effect of ACTH, renin, angiotensin II, and various precursors on biosynthesis of aldosterone by adrenal slices. J. Clin. Invest. 41:715-724.

4. Kojima, I., K. Kojima, D. Kreutter, and H. Rasmussen. 1984. The temporal integration of the aldosterone secretory response to angiotensin occurs via two intracellular pathways. J. Biol. Chem. 259:14448-14457.

5. Fakunding, J. L., R. Chow, and K. J. Catt. 1979. The role of calcium in the stimulation of aldosterone production by adrenocorticotropin, angiotensin II and potassium in isolated glomerulosa cells. Endocrinology. 105:327-333.

6. Braley, L. M., A. I. Menachery, E. M. Brown, and G. H. Williams. 1986. Comparative effect of angiotensin II, potassium, adrenocorticotropin and cyclic adenosine 3',5-monophosphate on cytosolic calcium in rat adrenal cells. Endocrinology. 119:1010-1019.

7. Hunyady, L., T. Balla, P. Enyedi, and A. Spat. 1985. The effect of angiotensin II on arachidonate metabolism in adrenal glomerulosa cells. Biochem. Pharmacol. 34:3439-3444.

8. Matsuoka, H., S. Y. Tan, and P. J. Mulrow. 1980. Effects of prostaglandins on adrenal steroidogenesis in the rat. Prostaglandins. 19:291-298.

9. Campbell, W. B., and C. Gomez-Sanchez. 1985. Absence of prostacyclin involvement in angiotensin-induced aldosterone secretion in rat adrenal cells. Endocrinology. 117:279-286.

10. Miller, R. T., J. G. Douglas, and M. J. Dunn. 1980. Dissociation of aldosterone and prostaglandin biosynthesis in the rat adrenal glomerulosa. Prostaglandins. 20:449-462.

11. Schwartz, S. L., and G. H. William. 1983. Role of prostaglandins in adrenal steroidogenesis. Endocrinology. 113:992-996.

12. Metz, S., M. VanRollins, R. Strife, W. Fujimoto, and R. P. 
Robertson. 1983. Lipoxygenase pathway in islet endocrine cells. Oxidative metabolism of arachidonic acid promotes insulin release. $J$. Clin. Invest. 71:1191-1205.

13. Turk, J., J. R. Colca, and M. L. McDaniel. 1985. Arachidonic acid metabolism in isolated pancreatic islets III effects of exogenous lipoxygenase products and inhibitors on insulin secretion. Biochim. Biophys. Acta. 834:23-26.

14. Braley, L. M., and G. H. Williams. 1977. Rat adrenal cell sensitivity to AII, $\alpha 1-24 \mathrm{ACTH}$ and $\mathrm{K}^{+}$, a comparative study. Am. $J$. Physiol. 233:402-406.

15. Sekiya, K., and H. Okuda. 1982. Selective inhibition of platelet lipoxygenase by baicalein. Biochem. Biophys. Res. Commun. 105:1090-1095.

16. Sun, F. F., and J. C. McGuire. 1983. Inhibition of human neutrophil arachidonate 5-lipoxygenase by 6,9-deepoxy-6,9-(phenylimino)-6,8-prostaglandin I, (U-60257). Prostaglandins. 26:211-221.

17. Douglas, J., G. Aguilera, T. Kondo, and K. J. Catt. 1978. Angiotensin II receptors and aldosterone production in rat adrenal glomerulosa cells. Endocrinology. 102:685-696.

18. Powell, W. 1982. Rapid extraction of arachidonic acid metabolites from biologic samples using octadecylsilyl silica. Methods Enzymol. 86:467-477.

19. Peters, P. P., E. S. Schulman, M. C. Liu, E. C. Hayes, and L. M. Lichtenstein. 1983. Separation of major prostaglandins leukotrienes and monohydroxyeicosatetraenoic acid by HPLC. J. Immunol. Methods. 64:335-343.

20. Levine, L., I. Alan, H. Gjika, T. J. Carty, and E. J. Goetzl. 1980. The development of a radioimmunoassay for 12-L hydroxyeicosatetraenoic acid. Prostaglandins. 20:923-934.

21. Mayes, D., S. Furuyama, D. C. Kem, and C. A. Nugent. 1970. A radioimmunoassay for plasma aldosterone. J. Clin. Endocrinol. Metab. 30:682-685.

22. Elliot, M. E., R. C. Alexander, and T. L. Goodfriend. 1982. Aspects of angiotensin action in the adrenal. Key roles for calcium and phosphatidyl inositol. Hypertension. 4:(Suppl. 2):52-58.

23. Farese, R. V., R. E. Larsson, M. A. Sabir, and C. Gomez-Sanchez. 1981. Effects of angiotensin-II and potassium on phospholipid metabolism in adrenal zona glomerulosa. J. Biol. Chem. 256:1109311097.

24. Griendling, K. K., S. E. Rittenhouse, T. A. Brock, L. S. Ekstein, M. A. Gimbrone, Jr., and R. W. Alexander. 1986. Sustained diacylglycerol formation from inositol phospholipids in angiotensin II-stimulated vascular smooth muscle cells. J. Biol. Chem. 261:5901-5906.

25. Frohlich, J. C., J. W. Hollifield, J. C. Dormois, B. L. Frolich, A. Seyberth, A. M. Michelakis, and J. A. Oates. 1976. Suppression of plasma renin activity by indomethacin in man. Circ. Res. 39:447-452.

26. Kojima, I., K. Kojima, and H. Rasmussen. 1985. Possible role of phospholipase A2 action and arachidonic acid metabolism in angiotensin II-mediated aldosterone secretion. Endocrinology. 117:1057-1066.

27. Campbell, W. B., C. Gomez-Sanchez, and B. V. Adams. 1980. Role of prostaglandins in angiotensin-induced steroidogenesis. Absence of an effect by PGE2. Hypertension. 2:471-476.

28. Campbell, W. B., C. Gomez-Sanchez, B. V. Adams, J. M. Schmitz, and H. D. Itskovitz. 1979. Attenuation of angiotensin II and III-induced aldosterone release by prostaglandin synthesis inhibitors. J. Clin. Invest. 64:1552-1557.

29. Campbell, W. B., M. T. Brady, and C. Gomez-Sanchez. 1986.
Effects of angiotensin, prostaglandin E2 and indomethacin on the early and late steps of aldosterone biosynthesis in isolated adrenal cells. J. Steroid. Biochem. 24:865-870.

30. Clark, D. L., and J. Linden. 1986. Modulation of guanylate cyclase by lipoxygenase inhibitors. Hypertension. 8:947-950.

31. Hageman, W. E., M. P. Rose, and F. J. Persico. 1986. Antagonism by ETYA of the effects of leukotrienes on ileum and lung parenchymal strips independent of effects on arachidonic acid metabolism. Prostaglandins. 32:563-567.

32. Breetens, J. R., W. Loots, Y. Somers, M. C. Coone, and F. DeClerck. 1986. Ketoconazole inhibits the biosynthesis of leukotrienes in vitro and in vivo. Biochem. Pharmacol. 35:883-891.

33. Hirai, A., K. Tahara, Y. Tamura, H. Saito, T. Terano, and S. Yoshida. 1985. Involvement of 5 lipoxygenase metabolites in ACTHstimulated corticosteroidogenesis in rat adrenal glands. Prostaglandins. 30:749-767.

34. Hansson, A., C. N. Serhan, M. Haeggstrom, M. IngelmanSunberg and B. Samuelsson. 1986. Activation of protein kinase C by lipoxin $A$ and other eicosanoids, intracellular action of oxygenation products of arachidonic acid. Biochem. Biophys. Res. Commun. 134:1215-1222.

35. Nakao, J., I. Hideki, T. Ooyama, W. C. Chang, and S. I. Muroto. 1983. Calcium dependency of aortic smooth muscle cell migration induced by 12 -L-hydroxy-5,8,10,14-eicostate-traenoic acid. Atherosclerosis. 46:309-319.

36. Metz, S. A., B. Drazin, K. E. Sussman, and J. W. Leitner. 1987. Unmasking of arachidonic-acid induced insulin release by removal of extracellular calcium. Biochem. Biophys. Res. Commun. 142:251258.

37. Abou-Samra, A., K. J. Catt, and G. Aguilera. 1986. Role of arachidonic acid in the regulation of adrenocorticotropin release from rat anterior pituitary cultures. Endocrinology. 119:1427-1431.

38. Naor, Z., L. Kiesel, J. Y. Vanderhoek, and K. J. Catt. 1985. Mechanism of action of gonadotropin releasing hormone. Role of lipoxygense products of arachidonic acid in lutenizing hormone release. J. Steroid Biochem. 23:711-717.

39. Snyder, G. D., J. Capdevilla, W. Chacos, S. Manna, and J. R. Falck. 1983. Action of luteinizing hormone-releasing hormone, involvement of novel arachidonic acid metabolites. Proc. Natl. Acad. Sci. USA. 80:3504-3508.

40. Dix, C. J., A. D. Hobberfield, H. F. Sullivan, and B. A. Cooke. 1984. Inhibition of steroid production in leydig cells by non-steroidal and related compounds: evidence for the involvement of lipoxygenase products in steroidogenesis. Biochem. J. 219:529-537.

41. Metz, S. A. 1985. Glucose increases the synthesis of lipoxygenase-mediated metabolites of arachidonic acid in intact rat islets. Proc. Natl. Acad. Sci. USA 82:198-202.

42. Capdevila, J., L. J. Marnett, N. Chacos, R. A. Prough, and R. W. Estabrook. 1982. Cytochrome P450 dependent oxygenation of arachidonic acid to hydroxycocosatetraenic acids. Proc. Natl. Acad. Sci. USA 79:767-770.

43. Ohiv, E. H., J. A. Lawson, A. R. Brash, and J. A. Oates. 1981. Arachidonic acid metabolism in rabbit renal cortex: formation of two novel dihydroxyeicosatetraenic acids. J. Biol. Chem. 256:9924-9931.

44. Ferreri, H. R., M. Schwartzman, N. G. Ibraham, P. N. Chander, and J. C. McGiff. 1984. Arachidonic acid metabolism in a cell suspension isolated from rabbit renal outer medulla. J. Pharm. Exp. Ther. 231:441-448. 